\title{
USABILITY TESTING PADA WEBSITE D'BUCKET KARAWANG MENGGUNAKAN NIELSEN MODEL
}

\section{USABILITY TESTING ON THE D'BUCKET KARAWANG WEBSITE USING NIELSEN MODEL}

\author{
Nur Aldien Ramadhania ${ }^{1}$, Aulia Fashanah Hadining ${ }^{2}$, Winarno ${ }^{3}$ \\ ${ }^{123}$ Universitas Singaperbangsa Karawang \\ nur.aldienramadhania16104@student.unsika.ac.id
}

\begin{abstract}
This study aims to test the D'Bucket Karawang website. Especially on the usability aspect based on the Nielsen Model using the usability testing method. The research method used is descriptive quantitative method and verification. Data collection was carried out by distributing questionnaires to 100 students in Karawang Regency. Data processing uses multiple linear regression analysis which is processed using IBM SPSS 22 software. The results of this study are the factors that affect the usability of D'Bucket Karawang website, namely Learnability (LN), Memorability (MO), Efficiency (EF), Error ( ER), and Satisfaction $(S F)$. The five factors simultaneously influence usability. Based on the research results, the most significant factor that affects users in the usability of the D'Bucket Karawang website is satisfaction, there is one variable that has a positive and significant effect on usability on the D'Bucket Karawang website, namely the user satisfaction variable.
\end{abstract}

Keywords: Usability, Learnability, Memorability, Efficiency, Errors, Satisfaction, Nielsen Model.

\begin{abstract}
ABSTRAK
Penelitian ini bertujuan untuk melakukan pengujian terhadap website D’Bucket Karawang. Khususnya pada aspek usability berdasarkan Nielsen Model dengan menggunakan metode usability testing. Metode penelitian yang dilakukan mengunakan metode kuantitatif deskriptif dan verifikati. Pengumpulan data dilakukan melalui penyebaran kuesioner kepada 100 mahasiswa di Kabupaten Karawang. Pengolahan data menggunakan analisis regresi linier berganda yang diolah dengan menggunakan software IBM SPSS 22. Hasil dari penelitian ini adalah Faktor-faktor yang mempengaruhi usability website D'Bucket Karawang yaitu Learnability (LN), Memorability (MO), Efficiency (EF), Error (ER), dan Satisfaction (SF). Kelima faktor tersebut memberikan pengaruh secara simultan terhadap usability. Berdasarkan hasil penelitian, faktor yang paling signifikan yang mempengaruhi pengguna dalam usability website D'Bucket Karawang yaitu satisfaction, terdapat satu variabel yang berpengaruh secara positif dan signifikan terhadap usability pada website D’Bucket Karawang, yaitu variabel kepuasan pengguna.
\end{abstract}

Kata Kunci: Usability, Learnability, Memorability, Efficiency, Errors, Satisfaction, Nielsen Model.

\section{PENDAHULUAN}

Salah satu dampak dari kemajuan teknologi sistem informasi saat ini adalah perkembangan situs web atau yang lebih dikenal sebagai website. Website adalah kumpulan halaman yang digunakan untuk menampilkan informasi teks, gambar diam atau gerak, animasi, suara atau kombinasinya (termasuk statis dan dinamis), halaman tersebut merupakan rangkaian dari bangunan yang saling berhubungan, yang masing-masing dihubungkan dengan jaringan-jaringan halaman (Suratna, 2021). Saat ini website merupakan salah satu layanan informasi yang banyak di akses oleh pengguna internet di dunia(Krzewińska, dkk., 2018).

Penelitian yang dilakukan Nielsen mendefinisikan usability sebagai suatu pengalaman pengguna dalam berinteraksi dengan aplikasi atau situs web sampai pengguna dapat mengoperasikannya dengan mudah dan cepat. Seperti halnya dalam penyedia 
informasi, setiap pelanggan akan selalu mengharapkan informasi yang memadahi aspek-aspek usability meliputi efektivitas, efisiensi, memorability, learnability, dan satisfaction(Sani, dkk., 2019). Nielsen juga merumuskan faktor-faktor penyebab pentingnya website memiliki aspek usability, diantaranya adalah kebiasaan atau perilaku pengguna yang mengakses website(Fajarini, dkk., 2020; Soejono, dkk., 2018).

Teknologi sistem informasi sudah banyak dimanfaatkan dalam kehidupan sehari-hari, tetapi tidak semua sistem informasi pernah melalui tahap pengujian usability. Hal ini disebabkan oleh faktor permasalahan yang masih terpusat pada pengelolaan kebutuhan, jadwal, dan sumber daya yang tersedia untuk implementasi sistem tersebut. Sedangkan pengukuran usability sistem dari sudut pengguna masih dianggap bukan kebutuhan utama dalam pengembangan sebuah sistem, sehingga sangat jarang dilakukan (Setiawan \& Rafianto, 2020; Muqtadiroh, dkk., 2017, ).

D'Bucket Karawang adalah usaha mikro kecil dan menengah (UMKM) yang baru memiliki sebuah website dalam memasarkan produknya. Website ini memuat informasi tentang D'Bucket Karawang mulai dari informasi produk, informasi harga, formulir pembelian, alamat, kontak, dan lainnya. Karena website ini masih terbilang baru, oleh sebab itu website D'bucket Karawang perlu adanya evaluasi untuk mengukur kemudahan penggunaan website bagi pengguna.

Penelitian ini bertujuan untuk melakukan evaluasi terhadap website D'Bucket Karawang. Khususnya pada aspek usability berdasarkan Nielsen Model dengan menggunakan metode usability testing(Febrianti, dkk., 2020; Nielsen, 2000).

\section{METODE}

Penelitian ini menjelaskan tentang model Nielsen dimana dimana faktor usability yang diukur terdiri atas learnability, memorability, efficiency, errors, dan satisfaction yang digunakan dalam penelitian ini(Liew, dkk., 2019).

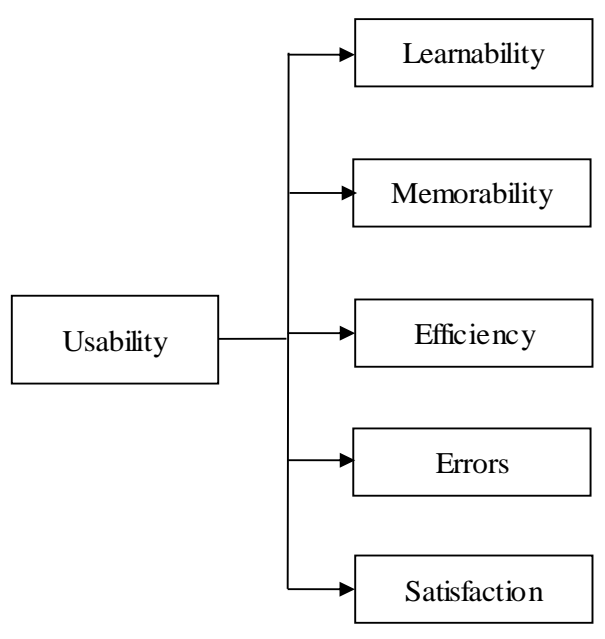

Gambar 1. Model Dasar Penelitian

Berdasarkan penelitian tersebut, hasil yang diperoleh pada Nielsen Model yang berfokus dalam bidang pengembangan usability website memuat unsur-unsur tolak ukur keberhasilan usability testing website.

Variabel penelitian yang digunakan terdiri dari dua jenis variabel yaitu variabel dependen dan variabel independen. Berikut merupakan penjelasan mengenai variabel Independen yaitu Learnability (X1), Efficiency (X2), Memorability (X3), Error(X4), Satisfaction (X5). Sedangkan variabel dependen yaitu Usability (Y).

Sampel yang digunakan dalam penelitian ini adalah 100 mahasiswa/i di daerah Karawang yang belum pernah melakukan pembelian buket makanan melalui website dan belum pernah menggunakan website D'Bucket Karawang. 
Metode pengumpulan data yang dilakukan dalam penelitian ini adalah kuisoner dan Studi Pustaka. Pada tahap ini pengolahan dan analisis data dilakukan dengan bantuan program Software Microsoft Excel 2016 dan IBM Statistical Package for Social Sciences (SPSS) versi 22.0. Microsoft Excel digunakan untuk input data dan digunakan untuk olah data awal yang selanjutnya akan digunakan untuk uji regresi linier.

\section{HASIL DAN PEMBAHASAN Statistik Deskriptif}

Tabel 1 Hasil Statistik Deskriptif

\begin{tabular}{|c|c|c|c|c|c|c|}
\hline $\begin{array}{c}\text { Variab } \\
\text { el }\end{array}$ & Kode & $\mathbf{N}$ & $\begin{array}{c}\text { Std. } \\
\text { Devia } \\
\text { tion }\end{array}$ & $\begin{array}{c}\text { Mean } \\
\text { (Indika } \\
\text { tor) }\end{array}$ & $\begin{array}{c}\text { Mean } \\
\text { /Varia } \\
\text { bel }\end{array}$ & $\begin{array}{c}\text { Ketera } \\
\text { ngan }\end{array}$ \\
\hline \multirow{6}{*}{$\begin{array}{l}\text { Learnab } \\
\text { ility } \\
(\mathrm{LN})\end{array}$} & LN1 & 100 & 0,586 & 4,40 & \multirow{6}{*}{4,25} & \multirow{6}{*}{$\begin{array}{c}\text { Sangat } \\
\text { setuju/ } \\
\text { Sangat } \\
\text { baik }\end{array}$} \\
\hline & LN2 & 100 & 0,617 & 4,23 & & \\
\hline & LN3 & 100 & 0,639 & 4,34 & & \\
\hline & LN4 & 100 & 0,695 & 4,32 & & \\
\hline & LN5 & 100 & 0,637 & 4,33 & & \\
\hline & LN6 & 100 & 0,685 & 4,07 & & \\
\hline \multirow{5}{*}{$\begin{array}{l}\text { Memora } \\
\text { bility } \\
\text { (MO) }\end{array}$} & MO1 & 100 & 0,743 & 4,21 & \multirow{5}{*}{4,04} & \multirow{5}{*}{$\begin{array}{l}\text { Setuju/ } \\
\text { Baik }\end{array}$} \\
\hline & MO2 & 100 & 0,688 & 4,03 & & \\
\hline & MO3 & 100 & 0,703 & 3,99 & & \\
\hline & MO4 & 100 & 0,636 & 4,20 & & \\
\hline & MO5 & 100 & 0,851 & 4,06 & & \\
\hline \multirow{5}{*}{$\begin{array}{l}\text { Efficien } \\
c y(\mathrm{EF})\end{array}$} & EF1 & 100 & 0,718 & 4,01 & \multirow{5}{*}{4,06} & \multirow{5}{*}{$\begin{array}{c}\text { Setuju/ } \\
\text { Baik }\end{array}$} \\
\hline & EF2 & 100 & 0,696 & 4,20 & & \\
\hline & EF3 & 100 & 0,656 & 4,12 & & \\
\hline & EF4 & 100 & 0,757 & 4,05 & & \\
\hline & EF5 & 100 & 0,925 & 4,05 & & \\
\hline \multirow{4}{*}{$\begin{array}{l}\text { Error } \\
\text { (ER) }\end{array}$} & ER1 & 100 & 1,094 & 2,57 & \multirow{4}{*}{3,05} & \multirow{4}{*}{$\begin{array}{c}\text { Netral/ } \\
\text { Kurang } \\
\text { Baik }\end{array}$} \\
\hline & ER2 & 100 & 1,059 & 2,64 & & \\
\hline & ER3 & 100 & 0,992 & 3,16 & & \\
\hline & ER4 & 100 & 0,845 & 3,65 & & \\
\hline \multirow{5}{*}{$\begin{array}{l}\text { Satisfac } \\
\text { tion } \\
(\mathrm{SF})\end{array}$} & SF1 & 100 & 0,697 & 4,28 & \multirow{5}{*}{4,1} & \multirow{5}{*}{$\begin{array}{c}\text { Setuju/ } \\
\text { Baik }\end{array}$} \\
\hline & SF2 & 100 & 0,829 & 4,17 & & \\
\hline & SF3 & 100 & 0,652 & 4,17 & & \\
\hline & SF4 & 100 & 0,783 & 4,05 & & \\
\hline & SF5 & 100 & 0,695 & 4,11 & & \\
\hline \multirow{5}{*}{$\begin{array}{l}\text { Usabilit } \\
y \text { (US) }\end{array}$} & US1 & 100 & 0,615 & 3,84 & \multirow{5}{*}{3,61} & \multirow{5}{*}{$\begin{array}{l}\text { Setuju/ } \\
\text { Baik }\end{array}$} \\
\hline & US2 & 100 & 0,732 & 3,90 & & \\
\hline & US3 & 100 & 0,775 & 3,69 & & \\
\hline & US4 & 100 & 0,696 & 4,00 & & \\
\hline & US5 & 100 & 1,153 & 2,62 & & \\
\hline
\end{tabular}

Sumber: Pengolahan Data SPSS (2020)
Hasil statistik deskriptif berdasarkan pengolahan IBM SPSS Statistics versi 22 maka dapat ditarik kesimpulan sebagai berikut:

1. Deskripsi Learnability (LN)

Hasil statistik deskriptif variabel Learnability (LN) memiliki nilai ratarata (mean) sebesar 4,25 berdasarkan skor kriteriaa rataan pada Tabel menunjukkan bahwa rata-rata jawaban persepsi responden adalah sangat setuju yang memiliki arti bahwa rataan jawabaan responden sangat setuju terhadap dengan pernyataan-pernyataan yang ada pada kuesioner Learnability (LN).

2. Deskriptif Memorability (MO)

Hasil statistik deskriptif variabel Memorability (MO) memiliki nilai ratarata (mean) sebesar 4,04 berdasarkan skor kriteriaa rataan pada Tabel menunjukkan bahwa rata-rata jawaban persepsi responden adalah setuju yang memiliki arti bahwa rataan jawabaan responden setuju terhadap dengan pernyataan-pernyataan yang ada pada kuesioner Memorability (MO).

3. Deskriptif Efficiency (EF)

Hasil statistik deskriptif variabel Efficiency (EF) memiliki nilai rata-rata (mean) sebesar 4,06 berdasarkan skor kriteria rataan pada Tabel menunjukkan bahwa rata-rata jawaban persepsi responden adalah setuju yang memiliki arti bahwa rataan jawabaan responden setuju terhadap dengan pernyataanpernyataan yang ada pada kuesioner Efficiency (EF).

4. Deskriptif Error (ER)

Hasil statistik deskriptif variabel Error (ER) memiliki nilai rata-rata (mean) sebesar 3,05 berdasarkan skor kriteriaa rataan pada Tabel menunjukkan bahwa rata-rata jawaban persepsi responden adalah netral yang memiliki arti bahwa rataan jawabaan responden kurang baik terhadap dengan 
pernyataan-pernyataan yang ada pada kuesioner Error (ER).

5. Deskriptif Satisfaction (SF)

Hasil statistik deskriptif variabel Satisfaction (SF) memiliki nilai rata-rata (mean) sebesar 4,1 berdasarkan skor kriteriaa rataan pada Tabel menunjukkan bahwa rata-rata jawaban persepsi responden adalah setuju yang memiliki arti bahwa rataan jawabaan responden setuju terhadap dengan pernyataanpernyataan yang ada pada kuesioner Satisfaction (SF).

6. Deskriptif Usability (US)

Hasil statistik deskriptif variabel Usability (US) memiliki nilai rata-rata (mean) sebesar 3,61 berdasarkan skor kriteriaa rataan pada Tabel menunjukkan bahwa rata-rata jawaban persepsi responden adalah setuju yang memiliki arti bahwa rataan jawabaan responden setuju terhadap dengan pernyataanpernyataan yang ada pada kuesioner Usability (US).

\section{Analisis Uji Validitas dan Reliabilitas}

\section{Uji Validitas}

Berdasarkan hasil uji validitas menunjukkan bahwa seluruh nilai $r$ hitung pada variabel dependen (usability) maupun variabel independen (Learnability, Memorability, Efficiency, Error, dan Satisfaction) memiliki nilai $\mathrm{r}$ hitung lebih besar daripada $r$ tabelnya $(0,3060)$. Hal ini menunjukkan bahwa uji validitas pada setiap variabel dinyatakan valid.

2. Uji Reliabilitas

Berdasarkan hasil Uji Reliabilitas menunjukkan bahwa seluruh variabel penelitian yaitu variabel dependen (usability) maupun variabel independen (Learnability, Memorability, Efficiency, Error, dan Satisfaction) memiliki nilai Cronbachs Alpha lebih dari 0,7 dan dapat ditarik kesimpulan bahwa seluruh variabel bersifat realibel karena responden mampu menjawab kuesioner. Dengan valid dan reliabelnya data maka selanjutnya dapat dilakukan uji asumsi klasik.

\section{Analisis Uji Asumsi Klasik}

1. Uji Normalitas

Tabel 2. Hasil Uji Normalitas

\begin{tabular}{cccc}
\hline Model & $\begin{array}{c}\text { Asymp. Sig } \\
\text { (2-tailded) }\end{array}$ & Kriteria & Kesimpulan \\
\hline $\begin{array}{c}\text { Unstandarized } \\
\text { Residual }\end{array}$ & 0,200 & $>0,05$ & $\begin{array}{c}\text { Data } \\
\text { Berdistribusi } \\
\text { Normal }\end{array}$ \\
\hline \multicolumn{2}{c}{ Sumber: Pengolahan Data SPSS 2020 }
\end{tabular}

Sumber: Pengolahan Data SPSS 2020

Hasil uji normalitas data yang telah

dilakukan berdasarkan metode

Kolmogorov Smirnov dengan

menggunakan IBM SPSS 22 yang ditunjukan oleh Tabel 4.14 menunjukan bahwa nilai Asymp. Sig. (2-tailed) sebesar 0.200 lebih besar dari 0.05 yang berarti data berdistribusi normal.

2. Uji Multikolinearitas

Tabel 3. Hasil Uji Multikolinearitas

\begin{tabular}{lccc}
\hline \multicolumn{1}{c}{ Variabel } & Tolerance & VIF & Kesimpulan \\
\hline Learnability & 0,349 & 2,862 & \\
\cline { 1 - 3 } Memorability & 0,490 & 2,039 & Terbebas dari \\
\cline { 1 - 3 } Efficiency & 0,287 & 3,486 & asumsi klasik \\
\cline { 1 - 2 } Error & 0,880 & 1,137 & nultikolinearitas \\
\cline { 1 - 2 } Satisfaction & 0,495 & 2,019 & \\
\hline \multicolumn{4}{c}{ Tolerance $>\mathbf{0 . 1 0}$} \\
\\
VIF $<\mathbf{1 0}$ & \\
\hline
\end{tabular}

Sumber Pengolahan Data SPSS 2020

Hasil uji multikolinearitas yang telah dilakukan terhadap variabel independen (Learnability, Memorability, Efficiency, Error, dan Satisfaction) menunjukkan nilai toleransi dan nilai VIF yang memenuhi kriteria uji multikolinearitas berada pada nilai toleransi sebesar 0,316 sampai dengan 0,979 yang mana nilai toleransi ini lebih dari 0,10 dan nilai VIF 1,021 sampai dengan 2,974 yang mana nilai VIFnya kurang dari 10 . Hal ini menunjukkan bahwa nilai-nilai dari hasil uji multikolinearitas memenuhi kriteria, sehingga dapat ditarik kesimpulan model regresi ini merupakan model yang baik karena tidak ditemukan adanya korelasi antar variabel independen (Learnability, 
Memorability, Efficiency, Error, dan Satisfaction).

\section{Uji Heterokedastisitas}

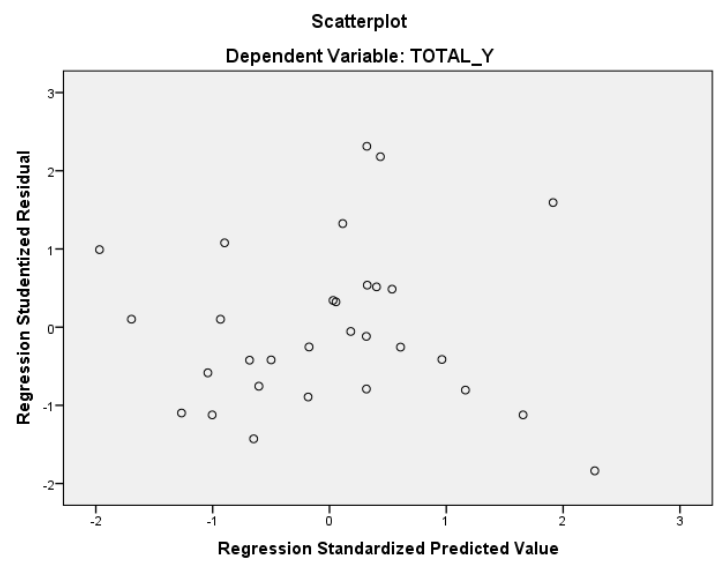

Gambar 1. Grafik Scatterplot

Hasil uji heterokedastisitas yang telah dilakukan dapat ditarik kesimpulan bahwa data menyebar dibawah atau diatas atau disekitar angka nol, titik tidak mengumpul dibawah atau diatas saja dan titik menyebar tidak membentuk pola bergelombang atau suatu pola yang jelas, maka dapat dinyatakan bahwa tidak terjadi masalah heteroskedastisitas, sehingga model regresi yang baik dan ideal dapat terpenuhi.

Berdasarkan ketiga uji asumsi klasik yang telah dilakukan (uji normalitas, uji multikolinearitas, dan uji heterokedastisitas) dapat ditarik kesimpulan bahwa seluruh data berdistribsui normal, lalu tidak ditemukan adanya korelasi antar variabel independen (Learnability, Memorability, Efficiency, Error, dan Satisfaction), dan tidak terjadi masalah heteroskedastisitas. Sehingga uji asumsi klasik yang baik terpenuhi.

\section{Uji Hipotesis}

\section{Uji T}

Pengujian koefisien regresi menggunakan tingkat kepercayaan 95\% (significat level 5\%, $\alpha=0.05$ ) dan dengan nilai $\mathrm{df}=\mathrm{d}-\mathrm{k}-1=30-5-1=24$.

Sehingga didapatkan $\mathrm{t}$ tabel yaitu 2,06390.

Tabel 4. Hasil Uji T

\begin{tabular}{lccc}
\hline \multicolumn{1}{c}{ Variabel } & t hitung & Sig. & Keterangan \\
\hline Learnabillity & 0,039 & 0,969 & Tidak Signifikan \\
\hline Memorabillity & 0,284 & 0,779 & Tidak Signifikan \\
\hline Efficiency & 1,193 & 0.245 & Tidak Signifikan \\
\hline Error & 0,365 & 0.718 & Tidak Signifikan \\
\hline Satisfaction & $-0,573$ & 0.572 & Tidak Signifikan \\
\hline \multicolumn{4}{c}{$\mathbf{t}$ tabel $=\mathbf{2 , 0 6 3 9 0}$} \\
\end{tabular}

Sumber: Pengolahan Data SPSS 2020

Berdasarkan uji $\mathrm{T}$ dapat dinyatakan bahwa variabel Satisfaction berpengaruh secara signifikan terhadap Usabillity website D'Bucket Karawang. Sedangkan untuk variabel Learnabillity, Memorabillity, Efficiency, dan Error tidak memiliki pengaruh secara signifikan terhadap Usabillity website D’Bucket Karawang.

\section{Uji F}

Untuk mengetahui f tabelnya maka dapat dihitung dengan menentukan df1 dan df2, dimana df $1=\mathrm{k}-1=6-1=5$, dan df2 $=\mathrm{n}-\mathrm{k}=100-6=94$ (Mutiara Nugrahani $\mathrm{dkk}, 2018$ ). Maka didapat $\mathrm{f}$ tabel yaitu 2,31 .

Tabel 5. Hasil Uji F

\begin{tabular}{ccc}
\hline Model & F hitung & Sig. \\
\hline Regression & 2,924 & 0,017
\end{tabular}

Sumber: Pengolahan Data SPSS (2020)

Pada Uji F dapat dilihat bahwa nilai $\mathrm{f}$ hitung lebih besar daripada $\mathrm{f}$ tabel yaitu $2,924>2.31$ dan nilai Sig. $0.017<0.05$ - Sehingga dapat dinyatakan bahwa seluruh hipotesis penelitian diterima, atau dengan kata lain variabel-variabel independen (Learnability, Memorability, Efficiency, Error, dan Satisfaction) secara simultan berpengaruh signifikan terhadap variabel dependen (Usability). 


\section{Koefisien Determinasi}

Berdasarkan hasil uji didapatkan nilai Adusted $R$ Square sebesar 0,135 yang berarti bahwa variabel-variabel independen penelitian dalam menjelaskan variasi variabel dependen terbatas.

\section{Analisis Regresi Liniear Berganda}

Tabel 6. Hasil Analisis Regresi Linier Berganda

\begin{tabular}{lc}
\hline \multicolumn{1}{c}{ Variabel } & B \\
\hline Constant (Y) & 9,940 \\
\hline Learnability (X1) & $-0,072$ \\
\hline Memorability (X2) & 0,060 \\
\hline Efficiency (X3) & 0,052 \\
\hline Error (X4) & 0,070 \\
\hline Satisfaction (X5) & 0,323 \\
\hline Sumber: Pengolahan Data SPSS (2020)
\end{tabular}

Sumber: Pengolahan Data SPSS (2020)

Hasil regresi linier berganda berdasarkan pengolahan IBM SPSS Statistics versi 22. Maka didapat persamaan sebagai berikut: $Y^{\prime}=9,940-0,072 X 1+0,060 X 2+$ $0,052 X 3+0,070 X 4+0,0323 X 5$

Berdasarkan Analisi Regresi Linier Berganda, maka tampak dilihat bahwa variabel Memorability, Efficiency, Error, dan Satisfaction berpengaruh secara positif terhadap Usability, sedangkan variabel learnability tidak berpengaruh secara positif terhadap Usability. Mengartikan tanda koefisien variabel independen dalam persamaan regresi linier berganda:

1. Koefisien $\mathrm{x} 1$ sebesar $-0,072$ artinya setiap 1 unit nilai $x 1$ akan berkurangnya nilai y1 sebesar 0,072

2. Kofisien $\mathrm{x} 2$ sebesar $+0,060$ artinya setiap 1 unit nilai $\mathrm{x} 2$ akan menambah nilai y1 sebesar 0,060

3. Koefisien $\times 3$ sebesar $+0,052$ artinya setiap 1 unit nilai $\mathrm{x} 3$ akan menambah nilai y1 sebesar 0,052
4. Koefisien $x 4$ sebesar $+0,070$ artinya setiap 1 unit nilai $\mathrm{x} 4$ akan menambah nilai y1 sebesar 0,070

5. Koefisien $\times 5$ sebesar $+0,032$ artinya setiap 1 unit nilai x5 akan menambah nilai y1 sebesar 0,032

\section{PEMBAHASAN}

Pembahasan Hipotesis

Pada tahap ini merupakan hasil pembahasan hipotesis berdasarkan pengolahan data yang telah dilakukan, berikut penerimaan hasil hipotesis dari setiap variabel :

1. Hipotesis 1 ditolak. Learnability berpengaruh positif dan signifikan terhadap Usability website D'Bucket Karawang.

Pernyataan bahwa variabel learnability (kemudahan) berpengaruh positif terhadap Usability tidak terbukti. Hal ini terjadi karena nilai $t$ variabel learnability untuk thitung $0.422<\mathrm{t}$ tabel 1.985 dan tidak signifikan $0.674>0.05$ dan juga nilai koefisien regresinya bernilai negatif sebesar -0.072 . Oleh karena itu, dapat disimpulkan bahwa hasil penelitian ini menunjukkan bahwa learnability tidak berpengaruh terhadap Usability website D'Bucket Karawang. Hal tersebut berbeda dengan penelitian terdahulu Muqtadiroh, dkk (2017) dimana learnability memberikan dampak positif dan signifikan.

2. Hipotesis 2 ditolak. Memorability berpengaruh positif dan signifikan terhadap Usability website D'Bucket Karawang.

Hasil uji t variabel memorability (daya ingat) yaitu sebesar (t hitung 0.392 $<\mathrm{t}$ tabel 1.985) dan tidak signifikan $(0.696>0.05)$ dan nilai koefisien regresinya (0.060) sehingga tidak mendukung hipotesis. Hasil penelitian ini menunjukkan bahwa daya ingat partisipan dalam menggunakan website memiliki pengaruh positif namun tidak 
signifikan terhadap evaluasi penggunaan website D'Bucket Karawang. Penelitian Muqtadiroh, dkk (2017) menunjukkan hal yang berbeda, dimana pada temuan penelitiannya menunjukkan bahwa memorability berpengaruh positif dan signifikan, hal tersebut mungkin bisa diakibatkan oleh objek penelitian yang berbeda.

3. Hipotesis 3 ditolak. Efficiency berpengaruh positif dan signifikan terhadap Usability website D'Bucket Karawang.

Berdasarkan hasil uji $\mathrm{t}$ variabel efficiency (efisiensi) yaitu sebesar ( $\mathrm{t}$ hitung $0.288<\mathrm{t}$ tabel 1.985) dan tidak signifikan $(0.774>0.05)$ dan nilai koefisien regresinya (0.052) sehingga tidak mendukung hipotesis. Oleh karena itu, dapat disimpulkan bahwa hasil penelitian ini menunjukkan bahwa efficiency dalam penggunaan website tidak berpengaruh terhadap Usability website D'Bucket Karawang. Sehingga hal tersebut selaras dengan penelitian terdahulu Muqtadiroh, dkk (2017) dimana efficiency tidak memberikan dampak positif dan signifikan.

4. Hipotesis 4 ditolak. Error berpengaruh positif dan signifikan terhadap Usability website D'Bucket Karawang.

Berdasarkan hasil uji $\mathrm{t}$ variabel error (kesalahan) yaitu sebesar (t hitung $0.774<\mathrm{t}$ tabel 1.985) dan tidak signifikan $(0.441>0.05)$ dan nilai koefisien regresinya (0.070) sehingga tidak mendukung hipotesis. Oleh karena itu, dapat disimpulkan bahwa hasil penelitian ini menunjukkan bahwa variabel error (kesalahan) yang ada pada sistem tidak berpengaruh terhadap Usability website D'Bucket Karawang. Hal tersebut selaras dengan penelitian terdahulu Muqtadiroh (2017) dimana variabel error tidak memberikan dampak positif dan signifikan, mungkin bisa diakibatkan oleh objek penelitian yang berbeda.

5. Hipotesis 5 diterima. Satisfaction berpengaruh positif dan signifikan terhadap Usability website D'Bucket Karawang.

Berdasarkan hasil uji $t$ variabel satisfaction (kepuasan) yaitu sebesar $(\mathrm{t}$ hitung $2.610>\mathrm{t}$ tabel 1.985) dan signifikan $(0.011<0.05)$ dan nilai koefisien regresinya bernilai positif (0.323) sehingga hal tersebut memenuhi syarat penerimaan hipotesis. Oleh karena itu, dapat disimpulkan bahwa hasil penelitian ini menunjukkan bahwa kepuasan pengguna dalam mencoba website berpengaruh terhadap Usability website D'Bucket Karawang, pengguna merasa puas setelah mencoba menggunakan website. Hal tersebut berbeda dengan penelitian terdahulu yang dilakukan oleh Muqtadiroh, dkk (2017) dimana satisfaction (kepuasan pengguna) tidak memberikan dampak positif dan signifikan

\section{SIMPULAN}

\section{Kesimpulan}

Berdasarkan hasil dan pembahasan pada bab sebelumnya, uji ketergunaan (usability testing) terhadap website D'Bucket Karawang dapat ditarik beberapa kesimpulan dalam penelitian ini. Kesimpulan dari penelitian ini adalah sebagai berikut:

1. Faktor-faktor yang mempengaruhi usability website D'Bucket Karawang yaitu Learnability (LN), Memorability (MO), Efficiency (EF), Error (ER), dan Satisfaction (SF). Kelima faktor tersebut memberikan pengaruh secara simultan terhadap usability dengan nilai uji F sebesar 2.924 serta nilai signifikansi sebesar 0.017 .

2. Berdasarkan hasil penelitian, faktor yang paling signifikan 
yang mempengaruhi pengguna dalam usability website D'Bucket Karawang yaitu satisfaction karena nilai uji $\mathrm{t}$ sebesar $2.610 \quad$ dengan signifikansi sebesar 0.011 serta nilai koefisien regresi (B) sebesar 0.323

\section{DAFTAR PUSTAKA}

Fajarini, P. T., Wirdiani, N. K. A., \& Dharmaadi, I. P. A. (2020). Evaluasi Portal Berita Online pada Aspek Usability Menggunakan Heurtistic Evaluation dan Think Aloud. Jurnal Teknologi Informasi dan Ilmu Komputer (JTIIK), 7(5).

Febrianti, D. A., Wijoyo, S. H., \& AzZahra, H. M. (2020). Evaluasi Usability Web UniPin dengan Menggunakan Metode Usability Testing. Jurnal Pengembangan Teknologi Informasi dan Ilmu Komputer e-ISSN, 2548, 964X.

Krzewińska, J., Indyka-Piasecka, A., Kopel, M., Kukla, E., Telec, Z., \& Trawiński, B. (2018, March). Usability testing of a responsive web system for a school for disabled children. In Asian Conference on Intelligent Information and Database Systems (pp. 705-716). Springer, Cham.

Liew, M. S., Zhang, J., See, J., \& Ong, Y. L. (2019). Usability challenges for health and wellness mobile apps: mixed-methods study among mHealth experts and consumers. JMIR mHealth and uHealth, 7(1), e12160.

Muqtadiroh, F. A., Astuti, H. M., Darmaningrat, E. W. T., \& Aprilian, F. R. (2017). Usability evaluation to enhance software quality of cultural conservation system based on nielsen model (wikibudaya). Procedia Computer Science, 124, 513-521.
Nielsen, J. (2000). Web usability. Apogeo Editore.

Sani, A., Wiliani, N., \& Husain, T. (2019). Spreadsheet Usability Testing in Nielsen's Model among Users of ITSMEs to Improve Company Performance. European Journal of Scientific Exploration, 2(6), 1-9.

Setiawan, D., \& Rafianto, N. (2020). Pengukuran usability pada learning management system perguruan tinggi menggunakan pedoman system usability scale. Teknologi: Jurnal Ilmiah Sistem Informasi, 10(1), 23-31.

Soejono, A. W., Setyanto, A., \& Sofyan, A. F. (2018). Evaluasi Usability Website UNRIYO Menggunakan System Usability Scale (Studi Kasus: Website UNRIYO). Respati, 13(1).

Suratna, M. A. (2021). Perancangan Sistem Informasi Pembayaran SPP Untuk Tingkat Sekolah Berbasis Web Dan Menggunakan SMS Gateway. Jurnal Industri Kreatif Dan Informatika Series (JIKIS), 1(1), 13-19. 